\title{
Discriminating among multiple components affecting bulk atmospheric deposition chemistry: a multivariate approach using data from a forest plot in Calabria (Southern Italy)
}

\author{
Silvia ARISCI*, Tiziana AMORIELLO ${ }^{1)}$, Rosario MOSELLO, Andrea COSTANTINI ${ }^{1)}$ and Maurizio BADIANI ${ }^{2}$ \\ CNR Institute of Ecosystem Study (ISE), 50 L.go Tonolli, 28922 Verbania Pallanza, Italy \\ ${ }^{1)}$ C.R.A. Experimental Institute for Plant Nutrition, 2-4 Via della Navicella, 00184 Rome, Italy \\ ${ }^{2)}$ Università Mediterranea di Reggio Calabria, Faculty of Agricultural Science, 89129, Italy \\ *e-mail corresponding author: s.arisci@ise.cnr.it
}

\begin{abstract}
This study examines the relationships between meteorology and atmospheric deposition chemistry on the basis of 4 years of monitoring in an area of Calabria (Piano Limina) under the National Integrated Programme for the Control of Forest Ecosystems. The location of the area and its low anthropogenic impact meant that phenomena of locally originating alkaline dust deposition could be distinguished from those originating long distances away. The analysis performed on the whole dataset revealed the interaction between temperature, solar radiation and ionic concentrations; the effects of the atmospheric transport of compounds, with lower concentrations during calm conditions; and a marked increase of calcium, alkalinity and $\mathrm{pH}$ with winds from W-SW, owing to the transport of alkaline dust from North Africa, in agreement with thematic maps on the synoptic scale. The possible influence of two volcanic events deriving from Stromboli and Etna is discussed. After elimination of the Saharan dust and volcanic events, a multivariate analysis showed the effects of compounds deriving from anthropogenic activities. Sulphate, nitrate and ammonium were closely correlated with $\mathrm{NW}$ winds; air masses from this direction come from the continental land mass and the sea, crossing the Calabrian plain before being deposited as precipitation on the Apennine chain. The component from NW also includes a high marine contribution, with maximum values of chloride and sodium.
\end{abstract}

Key words: atmospheric deposition chemistry, meteorology, Southern Italy, North African dust, atmospheric pollutants

\section{INTRODUCTION}

Following EU Regulation no. 1091/94, in 1995 the Italian Ministry for Agriculture and Forestry Policy, National Forest Service, launched the "National Integrated Programme for Forest Ecosystem Monitoring" (CONECOFOR), aimed at assessing the effects of atmospheric pollution and climate change on forest ecosystems. This programme also operates within the framework of the Convention on Long Range Transboundary Air Pollution of the United Nations Economic Commission for Europe (UN-ECE), ratified by Italy in 1982 (Petriccione \& Pompei 2002), and participates in two International Cooperative Programmes (ICP Forests and ICP Integrated Monitoring) (Kleemola \& Forsius 2004; de Vries et al. 2003). The level II CONECOFOR Programme is currently based on 31 permanent plots chosen to represent the highly variable geographical and climatic conditions of Italy, from the Alps to the south and the islands (Petriccione 2004).

Updates of the main results from the CONECOFOR Programme were presented by Ferretti et al. (1999, 2003, 2005) and by Mosello et al. (2002a). Most of the elaboration of the results has considered all of the permanent plots, observing any differences and analogies.
The aim of this paper is to examine in detail one of the permanent plots, Piano Limina in the Calabria Peninsula, chosen because of its central location in the Mediterranean Sea (Fig. 1), and to explore the influence of meteorological variables, at local and synoptic scale, on the chemistry of atmospheric deposition. Based on measurements performed from May 1999 to December 2003, the atmospheric deposition chemistry is examined in relation to the local meteorology, measured near and in the permanent plot, and in relation to the long range transport of Saharan dust, based on dust deposition maps and wind direction at synoptic scale. During the study, two strong volcanic emission events occurred which affected the deposition chemistry, i.e. 19/10/9909/11/99 (eruption of Etna), 29/07/03-05/08/03 (eruption of Stromboli). In a second step of the elaboration, we removed the contributions to the variance of the deposition chemistry due to Saharan dust and to the two volcanic events, analyzing the remaining data again in relation to local meteorology. This gave us a clearer idea of the contribution of human emissions and local suspension of dust to the chemistry of atmospheric deposition, and to infer the low impact of the eruptions of Etna and Stromboli. 

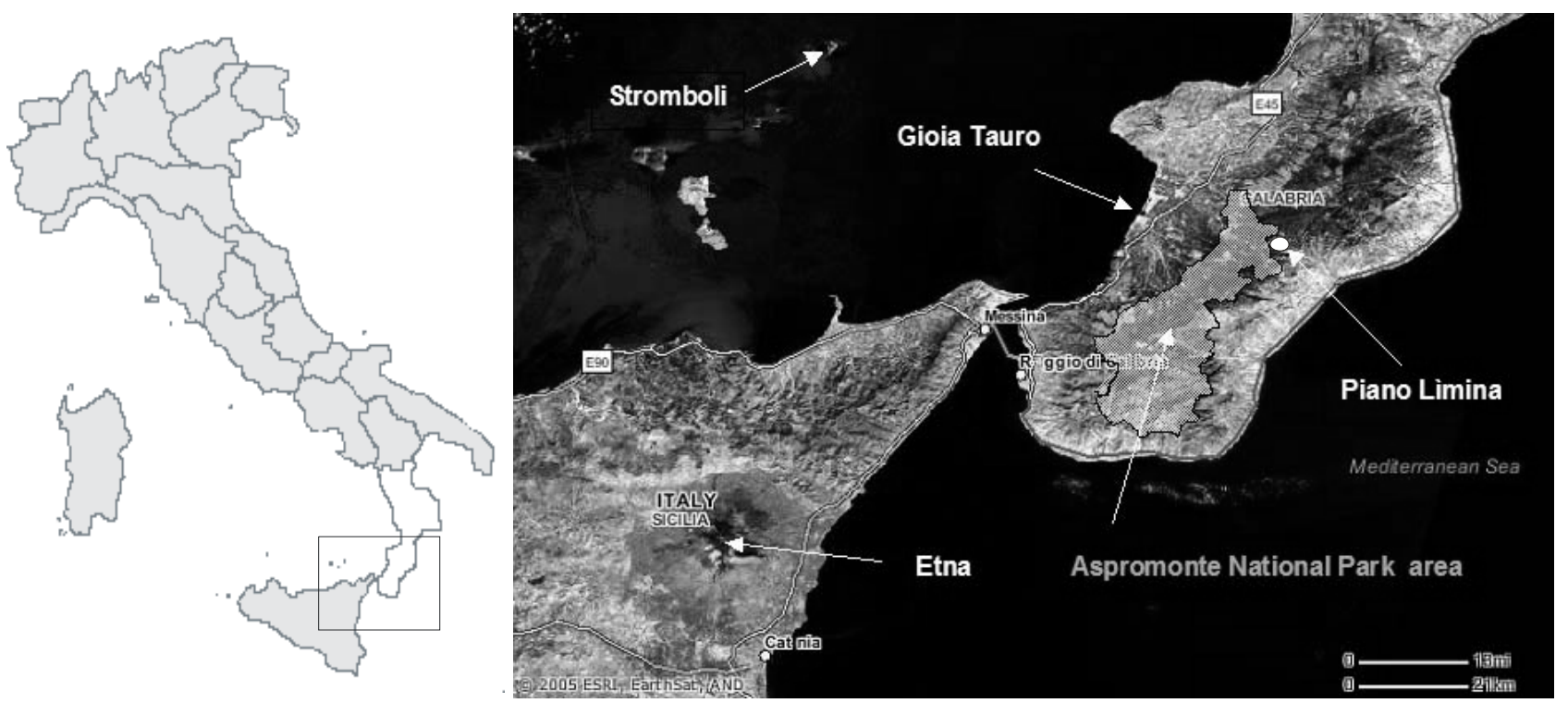

Fig. 1. Location of the permanent plot for atmospheric deposition chemistry, indicating the sampling station (Piano Limina) and the volcanoes Etna and Stromboli.

\section{METHODS}

\subsection{Study area}

The study area (Fig. 1 and Tab. 1) is located in the Aspromonte National Park, a roughly five-sided mountainous region of over $3200 \mathrm{~km}^{2}$, in Calabria. The Piano Limina area, at an altitude between 800 and $1,000 \mathrm{~m}$, is located about 30 and $20 \mathrm{~km}$ from the Tyrrhenian and Ionian seas, respectively. The geology of the Aspromonte is essentially composed of igneous rocks of the Calabro-Peloritan crystalline massif. The morphology of the area features rugged peaks and steep slopes (much of the territory is classed as having slopes steeper than $30 \%$ ). The agro-forest surface area of the territory comprises $91.5 \%$ of the total area, and the percentage of the area occupied by mountains is $68 \%$.

Tab. 1. Characteristics of the sampling station for open field deposition and for meteorological variables.

\begin{tabular}{ll}
\hline Location & Piano Limina, (RC) Calabria \\
Latitude & $38^{\circ} 25^{\prime} 30^{\prime \prime}$ \\
Longitude & $16^{\circ} 09^{\prime} 59^{\prime \prime}$ \\
Altitude & $900 \mathrm{~m}$ a.s.1. \\
Lithological substrate & granite \\
FAO classification & Podzols \\
Dominant tree specie & Fagus sylvatica \\
Mean tree age & $110 \mathrm{y}$ \\
\hline
\end{tabular}

The population is concentrated on the Tyrrhenian coast, in the towns on the Gioia Tauro Plain (Gioia Tauro, Rosarno, Palmi and Rizziconi), which possess more than $50 \%$ of the area's farms and industries (food sector, metal manufacturing, timber, machinery and electrical appliances). A key element in the industry of the area is the harbour of Gioia Tauro, one of the major container handling harbours in the world.

\subsection{Meteorology}

Meteorological data were collected in an open area located on the top of a smoothed hill, not sheltered by nearby obstacles or trees. Technical equipment and the type and placement of sensors are in accordance with the World Meteorological Organization Standards (W.M.O. 1969; Amoriello et al. 2002). The parameters considered in the study are: Air Temperature (AT), Relative Humidity (RH), Solar Radiation (SR) and Precipitation (PR) at $2 \mathrm{~m}$; Wind Speed (WS), the eight main sectors (north, N; north-east, NE; east, E; southeast, SE; south, S; south-west, SW; west, W; northwest, NW) of wind direction, and calm at $10 \mathrm{~m}$. Wind Speed is an arithmetic average over a period of $10 \mathrm{~min}$ utes. Calm is measured as time (as a percentage) passed with wind speed lower than the threshold of the instrument, equal to $0.2 \mathrm{~m} \mathrm{~s}^{-1}$. In this study we considered the wind direction only during all of the precipitation events in a week. Data are recorded with a CR10X Campbell Data-Logger. Once a week, the data are collected from the field and loaded into a database, as daily and hourly values (sum or average, min and max). The measurement period was from May 1999 to December 2003. The characteristics of the station for the measurement of meteorological data and atmospheric deposition for chemical analysis are shown in table 1.

So that we could compare the data from this study with those of a longer series, we used the data from the station of Piano Limina, managed by the Centro Funzionale Meteorologico Idrografico Mareografico of the Regional Environmental Protection Agency (www. idrocz.it). Located just a few kilometres from the study area, (latitude $38^{\circ} 23^{\prime} 32^{\prime \prime}$, longitude $16^{\circ} 12^{\prime} 24^{\prime \prime}$ ), at a slightly lower altitude (800 m a.s.l.), this station possesses data for the period 1992-2002. 


\subsection{Atmospheric deposition}

Three atmospheric deposition samples were collected weekly in the open field area using continuously exposed collectors (bulk), consisting of a 2-litre polyethylene bottle, equipped with a $19.6 \mathrm{~cm}$ diameter funnel. The three samples were pooled for the chemical analyses. A polyethylene net in the funnel prevented the collection of coarse debris, insects and leaves. The bottles were inserted into PVC cylinders of a slightly larger diameter, so as to have an air jacket around the bottle and to keep it shaded. By using more than one collector for each sampling point it was possible to discard any obviously contaminated subsamples without losing the entire sample for the period. The analyses were performed on filtered samples $(0.45 \mu \mathrm{m})$, except for the measurement of $\mathrm{pH}$ and conductivity, for which unfiltered samples were used. The variables examined were: $\mathrm{pH}$, conductivity and, by ion chromatography, sodium, potassium, magnesium, calcium, ammonium, sulphate, chloride, nitrate, alkalinity (samples with $\mathrm{pH}>5.0$, Gran's titration) and total nitrogen (Tartari \& Mosello 1997; Mosello et al. 2002b). Reactive phosphorus was also measured to reveal any contamination of the samples by bird droppings. Results were validated through a check of the ion balance and the comparison between measured conductivity and conductivity calculated from the product of each ion and its equivalent conductance. The data validation criteria and the internal and external QA/QC used in the laboratory fully agree with the guidelines of the Expert Panel on Deposition of the ICP Forests (Loevblad et al. 2004). The correction of concentrations for the marine contribution, indicated in the text with "*", was made on the basis of the ratio of each ion with chloride in sea water (O.E.C.D. 1979).

\subsection{Statistical methodology}

Cluster analysis is used to summarize the information contained in a set of chemical variables, by exploiting the similarities/dissimilarities (measured through Euclidean distance) between cases. To cluster our data, we used a hierarchical clustering algorithm, which operates by starting from a single "cluster" covering all the data, and then successively splitting into smaller clusters according to Ward's method. Ward proposed a clustering procedure that seeks to form the partitions $\mathrm{P}_{\mathrm{n}}, \mathrm{P}_{\mathrm{n}-1}, \ldots ., \mathrm{P}_{1}$ in a manner that minimizes the loss associated with each grouping, quantifying the loss in a form that is readily interpretable. At each step in the analysis, the union of every possible cluster pair is considered and the two clusters whose fusion results in the minimum increase in 'information loss' are combined. Information loss is defined by Ward in terms of an error sum-of-squares criterion. The result of this process is represented by a dendrogram or tree diagram (Anderberg 1973; Everitt et al. 2001).

Principal Component Analysis (PCA) is used to reveal how chemical and meteorological variables change in relation to each other, or how they are associated. This is achieved by transforming correlated original variables into a new set of uncorrelated underlying variables (called principal components) using the correlation matrix. PCA aims at reducing a large set of variables to a small set that still contains most of the information in the large set, by rotating the data so that maximum variabilities are projected onto the axes (Jolliffe 1986). More formally, it is a linear transformation that selects a new coordinate system for the data set, so that the greatest variance by any projection of the data set comes to lie on the first axis (then called the first principal component, PC1), the second greatest variance on the second axis (PC2), and so on. In this way, the uncorrelated variables are linear combinations of the original variables, and the last of these variables can be removed with minimum loss of real data. Communalities, e.g. the proportion of each variable's variance that can be explained by the principal components, are used. Variables with high values of communalities are well represented in the common factor space, while variables with low values are not well represented. The statistical analyses were performed using the SPSS (vers. 13.0) and Statistica (vers. 5.0 Statsoft) software.

\section{RESULTS}

\subsection{Meteorology}

The annual mean precipitation measured in the study area in the period $2000-2003$ was $1671 \mathrm{~mm}$, with low interannual variability (minimum 1541 in 2001, maximum 1794 in 2000, Tab. 2).

Tab. 2. Annual values of meteorological variables: AT (Air Temperature), RH (Relative air Humidity), SR (Solar Radiation), WS (Wind Speed) and PR (Precipitation). (1999 data do not cover the whole year).

\begin{tabular}{lccccc}
\hline & $\begin{array}{c}\mathrm{AT} \\
\left({ }^{\circ} \mathrm{C}\right)\end{array}$ & $\begin{array}{c}\mathrm{RH} \\
(\%)\end{array}$ & $\begin{array}{c}\mathrm{SR} \\
\left(\mathrm{W} \mathrm{m}^{-2}\right)\end{array}$ & $\begin{array}{c}\mathrm{WS} \\
\left(\mathrm{m} \mathrm{s}^{-1}\right)\end{array}$ & $\begin{array}{c}\mathrm{PR} \\
(\mathrm{mm})\end{array}$ \\
\hline 2000 & 10.3 & 84 & 145 & 1.8 & 1794 \\
2001 & 10.5 & 84 & 148 & 1.7 & 1541 \\
2002 & 10.9 & 89 & 142 & 1.7 & 1636 \\
2003 & 10.2 & 89 & 139 & 1.7 & 1714 \\
$2000-03$ & 10.5 & 86 & 144 & 1.7 & 1671 \\
\hline
\end{tabular}

The seasonal variability shows higher precipitation in winter and spring (Fig. 2). The data for the study period are not significantly different from those measured at the nearby station of Piano Limina, which possesses an 11-year series of measurements (Fig. 3). The mean annual precipitation at this station is $1572 \mathrm{~mm}$. An analysis of the distribution of precipitation for each month of the periods 2000-2003 (sampling station, Fig. 2) and 1992-2002 (reference station, Fig. 3a) reveals a typically Mediterranean climate: the rainiest months are in winter, while the summer months, especially June, with the exception of 1992, show very slight precipita- 


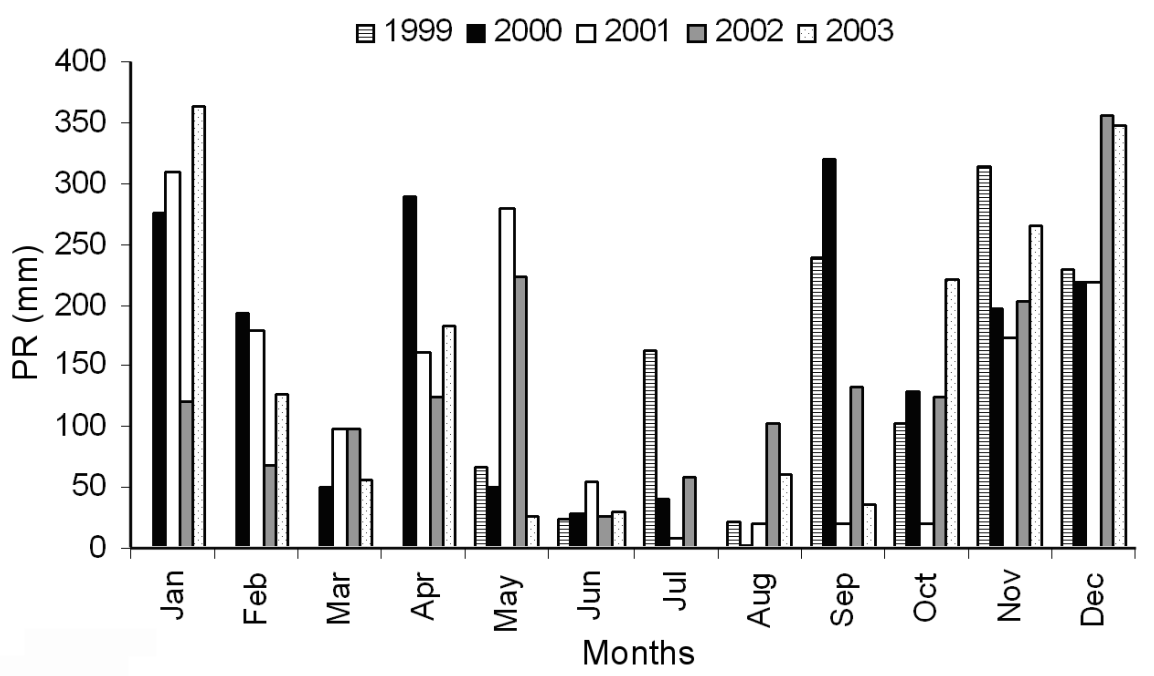

Fig. 2. Monthly precipitation values measured in the four study years (1999 data do not cover the whole year) at Piano Limina sampling station.
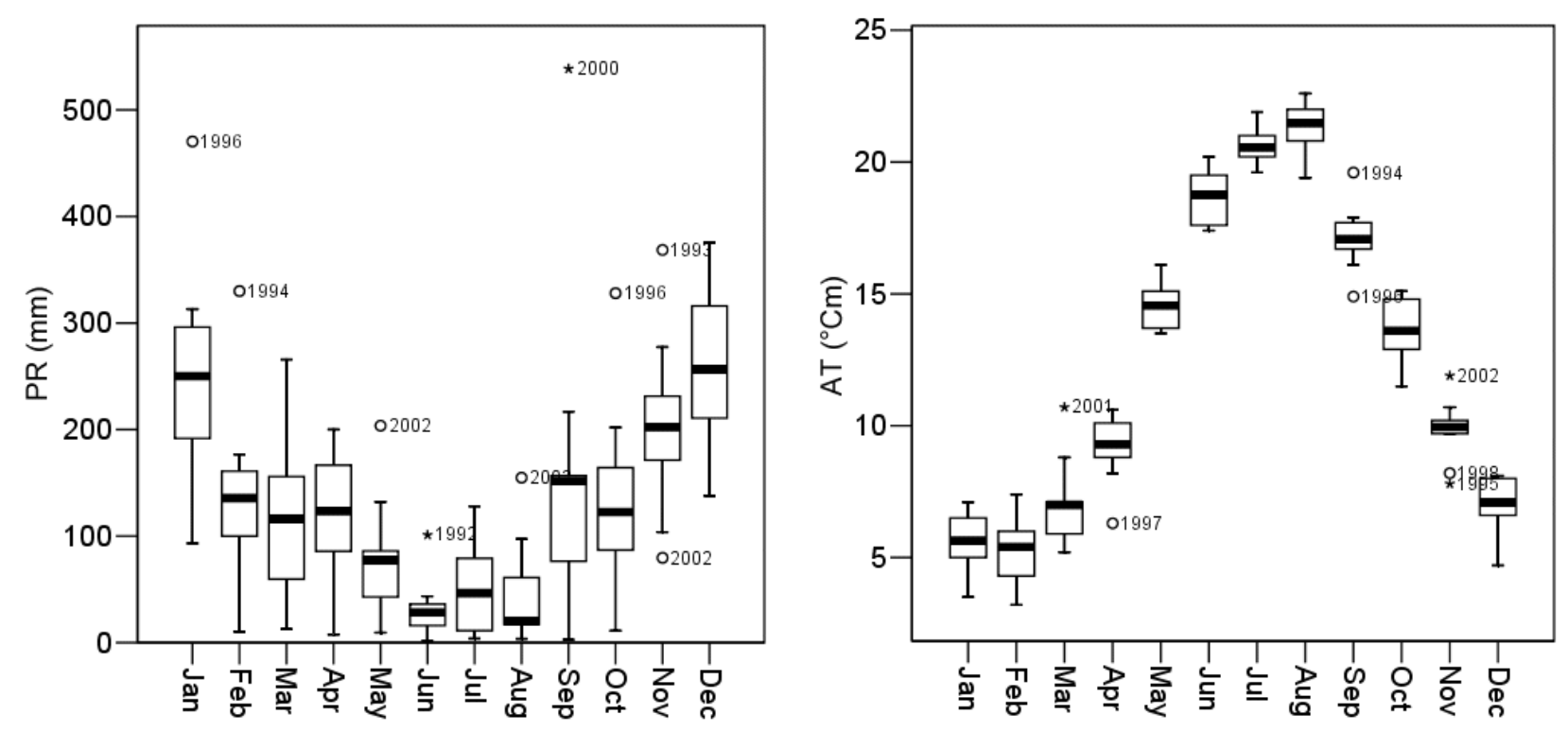

Fig. 3. Monthly values of precipitation (a) and of temperature (b) in the reference station (Limina); box plot indicating quartiles; $\left(^{\circ}\right)$ values higher than $1.5-3$ times the $2^{\text {nd }}-3^{\text {rd }}$ quartile range; $(*)$ values higher than 3 times the $2^{\text {nd }}-3^{\text {rd }}$ quartile range.

tion events. In addition, the interannual variability for each month is high. The distributions are all more or less asymmetrical. There are many outliers and an anomalous case in September 2000, when precipitation reached $538 \mathrm{~mm}$ in the station of Piano Limina and 320 $\mathrm{mm}$ in the study area.

The mean air temperature in the period 2000-2003 was $10.5^{\circ} \mathrm{C}$ (Fig. 4). During the summer months the mean temperatures fluctuated around $20{ }^{\circ} \mathrm{C}$, while in winter they were close to zero, falling below zero in January 2003. The maximum temperatures recorded during the study period were above $30{ }^{\circ} \mathrm{C}$ in summer, with a peak of $33.6{ }^{\circ} \mathrm{C}$ in July 2002 . The minimum tem- peratures between December and February fluctuated constantly between zero and $-8.9^{\circ} \mathrm{C}$, the latter recorded in December 2001. The mean temperature of the comparison period $1992-2002$ was $12.5^{\circ} \mathrm{C}$ (Fig. 3b), with a maximum of $13.0^{\circ} \mathrm{C}$ in 2001 and 2002 and a minimum of 11.8 in 1996. In the winter months the temperatures varied between 4 and $11{ }^{\circ} \mathrm{C}$; May and October are transitional months between the summer and winter periods, with abrupt changes of temperature of around $6{ }^{\circ} \mathrm{C}$; from June to September temperatures were between 16 and $23{ }^{\circ} \mathrm{C}$.

The difference between the temperatures recorded in the study area and those of the comparison area may be 

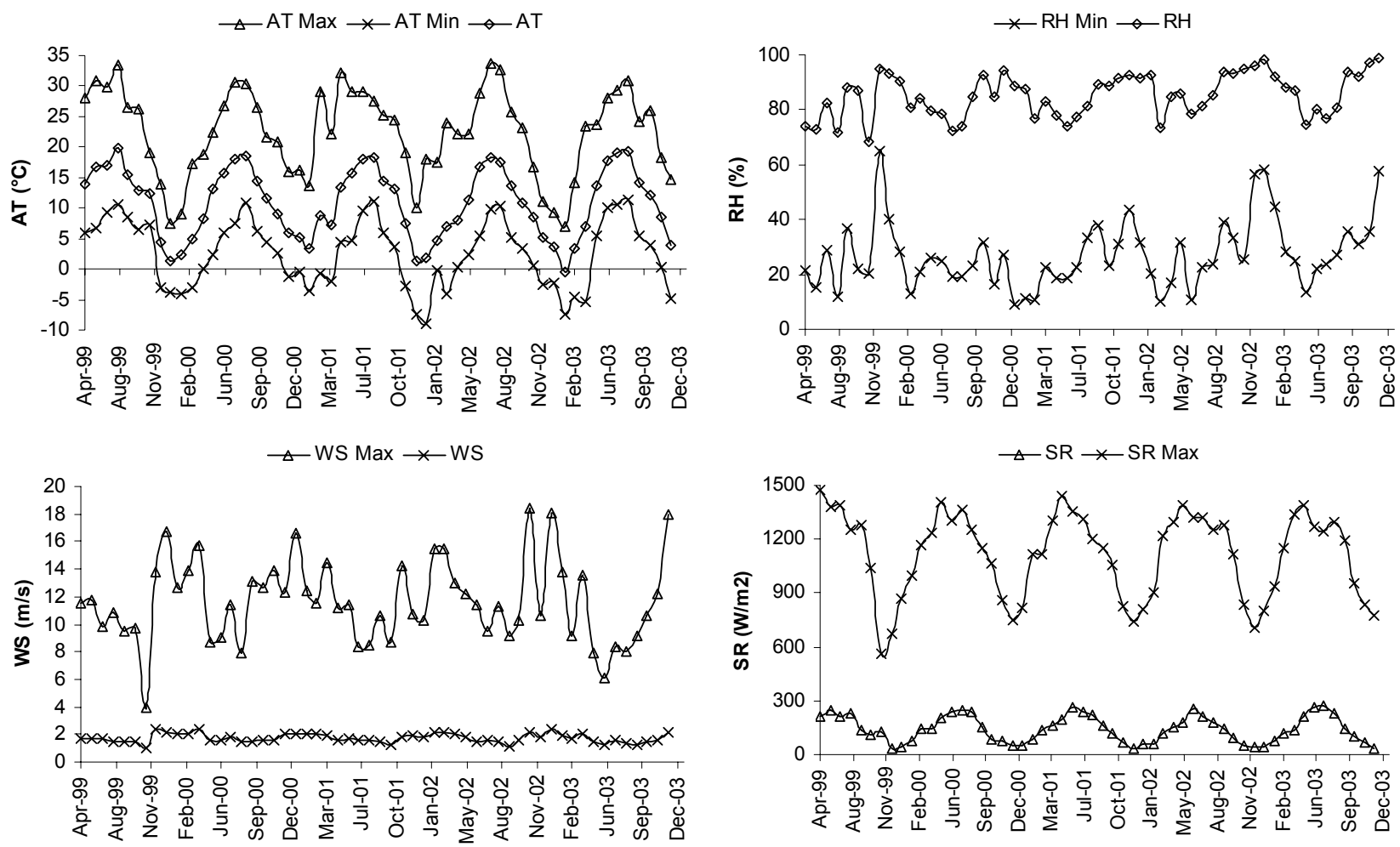

Fig. 4. Monthly means of air temperature (AT), relative air humidity (RH), wind speed (WS) and solar radiation (SR) in the study area.

attributed partly to the difference in altitude and partly to other geographical features such as exposure and direction of the slope.

The mean relative air humidity in the period 2000 2003 was $87 \%$, with fluctuations between $68 \%$ and $98 \%$ (Fig. 4), with summer minima of $70 \%$ and winter maxima of $98 \%$. The minimum relative humidity varied between $9 \%$ and $65 \%$. The relative air humidity trend closely follows the pluviometric regime shown in figure 2 .

The mean solar radiation in the period was $144 \mathrm{~W}$ $\mathrm{m}^{-2}$ (Fig. 4), while the maximum recorded reached a value of $1440 \mathrm{~W} \mathrm{~m}^{-2}$. The monthly trend increased from January to June, was more or less steady in summer, with the exception of 2002, and then decreased sensibly from September to the end of the year.

An analysis of the anemological regime shows that the wind speed was $1.7 \mathrm{~m} \mathrm{~s}^{-1}$, equivalent to a light breeze, with peaks of up to $19 \mathrm{~m} \mathrm{~s}^{-1}$ (Fig. 4). The wind rose shown in figure 5 reveals $8 \%$ calm conditions, and a net tendency for the wind to increase in the N (34\%) and NW (23\%) sectors. There was a very small percentage of wind in the other sectors (W: $9 \%, \mathrm{SW}: 4 \%, \mathrm{~S}$ : 5\%, SE: 5\%, E: 4\%, NE: $8 \%$ ).

\subsection{Chemistry of atmospheric deposition}

Annual volume-weighted ion concentrations in bulk deposition for the period 1999-2003 (Tab. 3) show the strong influence of marine spray; data are accordingly also presented corrected for sea salt contribution. In fact, sodium and chloride show the highest concentrations, and represent altogether $48 \%$ of the total ion concentrations; if the marine fraction of $\mathrm{Ca}^{2+}, \mathrm{Mg}^{2+}, \mathrm{SO}_{4}=$ and $\mathrm{K}^{+}$is also added, the fraction of marine contribution increases to $56 \%$.

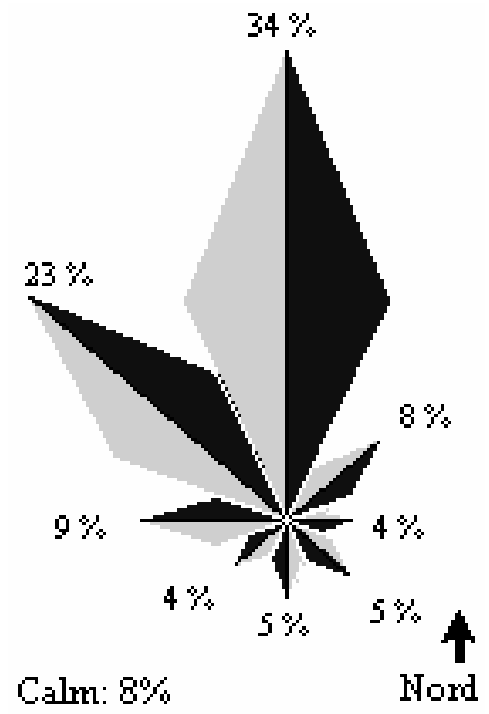

Fig. 5. Wind direction frequency in the study area (20002003). 
Tab. 3. Chemistry of atmospheric deposition in the study period. *: corrected for the marine contribution.

\begin{tabular}{|c|c|c|c|c|c|c|c|c|c|}
\hline & $\mathrm{pH}$ & $\begin{array}{c}\text { Cond. } \\
\left(\mu \mathrm{S} \mathrm{cm}^{-1}\right)\end{array}$ & $\begin{array}{c}\mathrm{H}^{+} \\
\left(\mu \mathrm{eq} \mathrm{L}^{-1}\right)\end{array}$ & $\begin{array}{c}\mathrm{NH}_{4}^{+} \\
\left(\mu \mathrm{eq} \mathrm{L} \mathrm{L}^{-1}\right)\end{array}$ & $\begin{array}{c}\mathrm{Ca}^{2+} \\
\left(\mu \mathrm{eq} \mathrm{L} \mathrm{L}^{-1}\right)\end{array}$ & $\begin{array}{c}\mathrm{Mg}^{2+} \\
\left(\mu \mathrm{eq} \mathrm{L} \mathrm{L}^{-1}\right)\end{array}$ & $\begin{array}{c}\mathrm{Na}^{+} \\
\left(\mu \mathrm{eq} \mathrm{L} \mathrm{L}^{-1}\right)\end{array}$ & $\begin{array}{c}\mathrm{K}^{+} \\
\left(\mu \mathrm{eq} \mathrm{L} \mathrm{L}^{-1}\right)\end{array}$ & $\begin{array}{c}\text { Alk } \\
\left(\mu \text { eq L }{ }^{-1}\right)\end{array}$ \\
\hline 1999 & 5.0 & 30 & 10 & 16 & 54 & 35 & 110 & 28 & 44 \\
\hline 2000 & 4.7 & 26 & 21 & 8 & 38 & 28 & 92 & 9 & 7 \\
\hline 2001 & 5.2 & 21 & 7 & 14 & 32 & 22 & 82 & 5 & 11 \\
\hline 2002 & 5.2 & 22 & 7 & 12 & 81 & 18 & 63 & 5 & 50 \\
\hline 2003 & 5.1 & 24 & 8 & 14 & 36 & 24 & 100 & 9 & 16 \\
\hline \multirow[t]{2}{*}{$1999-2003$} & 5.0 & 25 & 11 & 13 & 49 & 26 & 90 & 12 & 26 \\
\hline & $\begin{array}{c}\mathrm{SO}_{4}= \\
\left(\mu \mathrm{eq} \mathrm{L} \mathrm{L}^{-1}\right)\end{array}$ & $\begin{array}{c}\mathrm{NO}_{3}^{-} \\
\left(\mu \mathrm{eq} \mathrm{L}{ }^{-1}\right)\end{array}$ & $\begin{array}{c}\mathrm{Cl}^{-} \\
\left(\mu \mathrm{eq} \mathrm{L} \mathrm{L}^{-1}\right)\end{array}$ & $\begin{array}{c}* \mathrm{Ca}^{2+} \\
\left(\mu \mathrm{eq} \mathrm{L} \mathrm{L}^{-1}\right)\end{array}$ & $\begin{array}{c}* \mathrm{Mg}^{2+} \\
\left(\mu \mathrm{eq} \mathrm{L} \mathrm{L}^{-1}\right)\end{array}$ & $\begin{array}{c}* \mathrm{Na}^{+} \\
\left(\mu \mathrm{eq} \mathrm{L} \mathrm{L}^{-1}\right)\end{array}$ & $\begin{array}{c}* \mathrm{~K}^{+} \\
\left(\mu \mathrm{eq} \mathrm{L}^{-1}\right)\end{array}$ & $\begin{array}{c}* \mathrm{SO}_{4}{ }^{=} \\
\left.(\mu \mathrm{eq} \mathrm{L})^{-1}\right)\end{array}$ & $\begin{array}{l}\mathrm{TN} \\
\mu \mathrm{M}\end{array}$ \\
\hline 1999 & 58 & 18 & 116 & 50 & 12 & 11 & 26 & 46 & 52 \\
\hline 2000 & 48 & 19 & 107 & 34 & 7 & 0 & 7 & 37 & 46 \\
\hline 2001 & 40 & 17 & 95 & 28 & 4 & 1 & 3 & 30 & 42 \\
\hline 2002 & 46 & 18 & 67 & 78 & 4 & 5 & 4 & 39 & 37 \\
\hline 2003 & 44 & 18 & 107 & 32 & 4 & 8 & 7 & 33 & 42 \\
\hline $1999-2003$ & 48 & 18 & 99 & 45 & 6 & 5 & 10 & 37 & 44 \\
\hline
\end{tabular}

The common origin of $\mathrm{Na}$ and $\mathrm{Cl}^{-}$is underlined by the slope of the regression line, which gives a $\mathrm{Na}^{+} / \mathrm{Cl}^{-}$ molar ratio not significantly different from that of sea water $(0.86)$. Ion concentrations show a marked interannual variability: for example, alkalinity ranged between 50 and $7 \mu \mathrm{eq} \mathrm{L} \mathrm{L}^{-1}$ respectively in 2002 and 2000, well correlated with calcium concentrations. Most of these variations are due to long-range transport of calcareous dust, as discussed below. Annual $\mathrm{pH}$ values range from a lowest value of 4.7 in 2000 to values between 5.0 and 5.2 in the other years; $\mathrm{pH}$ is largely related to alkalinity and calcium concentrations. Sulphate and nitrate (mean values of 48 and $18 \mu \mathrm{eq} \mathrm{L}^{-1}$ ) show a lower interannual variability; the relative contribution of sea salt to sulphate is about $23 \%$ of the total.

As bulk collectors were used in the study, following the procedure adopted by the international program ICP Forests, there may be a contribution of local dust to the measured chemistry. We tried to minimize this aspect by locating the collecting site in a grass clearing close to the forested area, far from unpaved roads. This may partially explain the relationship between deposition chemistry and meteorology examined in this paper, in so far as contributes significantly to the solute concentrations from the re-suspension of dust from areas not far from the sampler. A comparison between wet-only and bulk deposition chemistry performed in (five) other Italian plots with characteristics not unlike those of the examined station shows higher values in bulk samples, by $20-30 \%$ for soil derived ions, while the relationship for anthropogenic and marine ions is between $10-20 \%$; in the end the relationship among ions remains unchanged (Balestrini et al. 2007).

The cluster analysis (Fig. 6) shows three distinct associations of ions, in relation to their origin: marine $\left(\mathrm{Na}^{+}, \mathrm{Cl}^{-}, \mathrm{Mg}^{2+}\right)$, terrestrial $\left(\mathrm{Ca}^{2+}\right.$, alkalinity, $\left.\mathrm{K}^{+}\right)$, anthropogenic emissions $\left(\mathrm{SO}_{4}{ }^{-}, \mathrm{NO}_{3}{ }^{-}, \mathrm{NH}_{4}{ }^{+}\right.$, total nitrogen, $\mathrm{H}^{+}$). In the case of sea salt corrected ion concentrations the cluster related to human emissions remains unchanged, while the terrestrial ions appear in two close clusters formed by ${ }^{*} \mathrm{Ca}^{2+}$ and alkalinity, ${ }^{*} \mathrm{Mg}^{2+}$ and ${ }^{*} \mathrm{~K}^{+}$. This points out the composite origin of magnesium, partly from sea water and partly from soil dust.

\section{DISCUSSION}

\subsection{Relationship between chemistry and meteorology}

Some of the chemical and meteorological variables considered in this study are determined by the same phenomenon. This can lead to the condition known as "multicollinearity", i.e. a high degree of correlation between variables (Belsley 1991). To test the measurement of the degree of multicollinearity in our data set, a simple if rough procedure could be the matrix of correlation between all the pairs of variables. A high frequency of highly significant correlations may be indicative of multicollinearity. However, the lack of large correlations does not guarantee the absence of multicollinearity among the variables. Moreover, there are no indications as to which variables should be eliminated or grouped together. This is why we decided to use cluster analysis on the chemical variables. The close connection between certain variables determined the choice of some of them as indicators, omitting others regarded in this case as superfluous. Selected chemical variables included $\mathrm{H}^{+}, \mathrm{NH}_{4}^{+}, \mathrm{NO}_{3}^{-}, * \mathrm{SO}_{4}{ }^{=}$, as representative of anthropogenic emissions, ${ }^{*} \mathrm{Ca}^{2+}, * \mathrm{Mg}^{2+}$, mainly due to soil dust, and $\mathrm{Cl}^{-}$, as an indicator of sea salt contribution $\left({ }^{*} \mathrm{Ca}^{2+}, * \mathrm{Mg}^{2+}\right.$ and $* \mathrm{SO}_{4}{ }^{*}$ concentrations were corrected for sea salt contribution, Tab. 4). Of the meteorological variables, we decided to exclude only calm, as it is complementary to the eight wind sectors. In fact, if our aim is to determine the relationships between all the different variables considered, a procedure which ignores or redefines meteorological variables, however strongly correlated, is not effective, because some important variables could be excluded from the analysis. The 13 meteorological variables were: solar radiation SR, air 

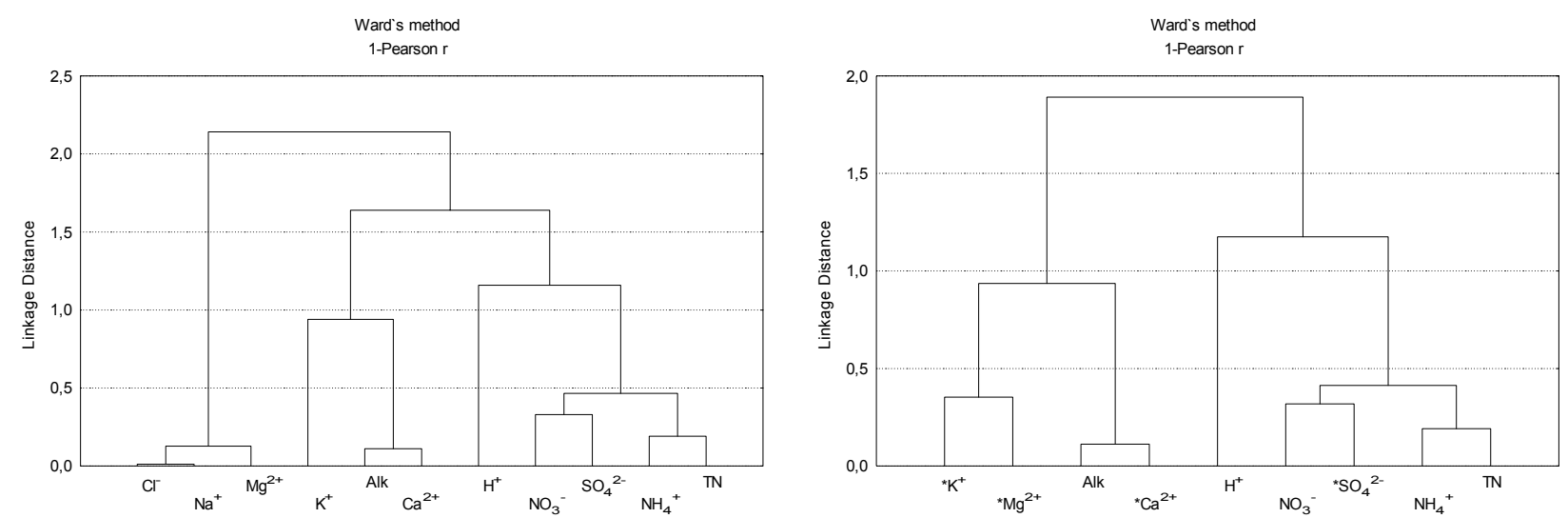

Fig. 6. Cluster analyses of the solutes present in atmospheric deposition without (left) and with (right) sea-salt correction.

Tab. 4. Meteorological and chemical variables used in the $\mathrm{PC}$ analyses using data from 96 weeks (upper line) and 85 weeks (lower line). AT (Air Temperature), RH (Relative air Humidity), SR (Solar Radiation), WS (Wind Speed) and PR (Precipitation); N, NE, E...: wind sectors.

\begin{tabular}{|c|c|c|c|c|c|c|c|c|c|c|c|c|c|c|}
\hline & $\begin{array}{l}\text { PR } \\
(\mathrm{mm})\end{array}$ & $\begin{array}{l}\mathrm{AT} \\
\left({ }^{\circ} \mathrm{C}\right)\end{array}$ & $\begin{array}{l}\mathrm{RH} \\
(\%)\end{array}$ & $\begin{array}{r}\mathrm{SH} \\
(\mathrm{W} r\end{array}$ & & $\begin{array}{c}\text { WS } \\
\left(\mathrm{m} \mathrm{s}^{-1}\right)\end{array}$ & $\mathrm{N}$ & NE & E & $\mathrm{SE}$ & S & SW & W & NW \\
\hline \multirow[t]{2}{*}{ Mean } & 65.6 & 9.3 & 89 & 11 & & 1.9 & 0.206 & 0.079 & 0.071 & 0.109 & 0.0 & 0.061 & 0.128 & 0.260 \\
\hline & 66.4 & 9.1 & 89 & 10 & & 1.9 & 0.210 & 0.078 & 0.068 & 0.105 & 0.0 & 0.060 & 0.129 & 0.266 \\
\hline \multirow[t]{2}{*}{ Median } & 54.2 & 9.9 & 91 & 10 & & 1.8 & 0.203 & 0.072 & 0.049 & 0.049 & 0.0 & 0.059 & 0.128 & 0.265 \\
\hline & 53.9 & 9.7 & 92 & 10 & & 1.8 & 0.208 & 0.071 & 0.043 & 0.043 & 0.0 & 0.058 & 0.128 & 0.269 \\
\hline \multirow[t]{2}{*}{ SD } & 47.1 & 5.1 & 9 & 62 & & 0.4 & 0.089 & 0.044 & 0.064 & 0.120 & 0.0 & 0.027 & 0.056 & 0.119 \\
\hline & 49.2 & 5.2 & 10 & 62 & & 0.4 & 0.091 & 0.041 & 0.064 & 0.123 & 0.0 & 0.026 & 0.057 & 0.123 \\
\hline \multirow[t]{2}{*}{ Min } & 11.0 & -0.1 & 40 & 30 & & 1.1 & 0.012 & 0.017 & 0.007 & 0.002 & 0.0 & 0.007 & 0.018 & 0.031 \\
\hline & 11.0 & -0.1 & 40 & 30 & & 1.1 & 0.012 & 0.017 & 0.007 & 0.002 & 0.0 & 0.007 & 0.018 & 0.031 \\
\hline \multirow[t]{3}{*}{ Max } & 219.8 & 20.3 & 99 & 26 & & 2.9 & 0.492 & 0.250 & 0.290 & 0.505 & 0.2 & 0.137 & 0.273 & 0.531 \\
\hline & 219.8 & 20.3 & 99 & 26 & & 2.9 & 0.492 & 0.224 & 0.290 & 0.505 & 0.2 & 0.133 & 0.273 & 0.531 \\
\hline & $\begin{array}{c}\mathrm{H}^{+} \\
\left(\mu \text { eq } 1^{-1}\right)\end{array}$ & $\begin{array}{c}\mathrm{NH}_{4}^{+} \\
\left(\mu \text { eq } 1^{-1}\right)\end{array}$ & $\begin{array}{r}{ }^{*} \mathrm{C} \\
(\mu \mathrm{eq}\end{array}$ & $\begin{array}{l}a^{2+} \\
\left.1^{-1}\right)\end{array}$ & $\begin{array}{l}{ }^{*} \mathrm{M} \\
(\mu \mathrm{e}\end{array}$ & $\begin{array}{l}\mathrm{Mg}^{2+} \\
\left.\mathrm{q}^{-1}\right)\end{array}$ & $\begin{array}{c}* \mathrm{Na}^{+} \\
\left(\mu \mathrm{eq} 1^{-1}\right)\end{array}$ & $\begin{array}{c}* \mathrm{~K}^{+} \\
\left(\mu \mathrm{eq} \mathrm{l}^{-1}\right)\end{array}$ & $\begin{array}{c}* \mathrm{SO}_{4}= \\
\left(\mu \text { eq } 1^{-1}\right)\end{array}$ & $\begin{array}{r}\mathrm{NO} \\
(\mu \mathrm{eq}\end{array}$ & & $\begin{array}{c}\mathrm{Cl}^{-} \\
\left(\mu \text { eq } 1^{-1}\right)\end{array}$ & $\begin{array}{c}\text { Alk } \\
\left(\mu \mathrm{eq} 1^{-1}\right)\end{array}$ & $\begin{array}{l}\mathrm{N} \text { tot } \\
(\mu \mathrm{M})\end{array}$ \\
\hline \multirow[t]{2}{*}{ Mean } & 11 & 16 & 5 & & & 8 & 6 & 12 & 45 & 23 & & 95 & 33 & 56 \\
\hline & 12 & 15 & 3 & & & 6 & 5 & 9 & 41 & 24 & & 91 & 14 & 56 \\
\hline \multirow[t]{2}{*}{ Median } & 3 & 9 & 3 & & & 5 & 3 & 4 & 37 & 20 & & 70 & 1 & 44 \\
\hline & 5 & 10 & 2 & & & 4 & 3 & 4 & 35 & 21 & & 67 & 0 & 44 \\
\hline \multirow[t]{2}{*}{ SD } & 14 & 19 & 8 & & & 11 & 16 & 31 & 28 & 16 & & 81 & 80 & 42 \\
\hline & 14 & 17 & 3 & & & 7 & 7 & 23 & 23 & 15 & & 77 & 30 & 39 \\
\hline \multirow[t]{2}{*}{ Min } & 0 & 0 & 3 & & & 0 & 0 & 1 & 6 & 0 & & 8 & 0 & 1 \\
\hline & 0 & 0 & 3 & & & 0 & 0 & 1 & 6 & 0 & & 8 & 0 & 9 \\
\hline \multirow[t]{2}{*}{ Max } & 65 & 117 & 63 & & & 57 & 147 & 203 & 158 & 76 & & 409 & 540 & 227 \\
\hline & 65 & 114 & 16 & & & 38 & 44 & 203 & 104 & 76 & & 393 & 216 & 220 \\
\hline
\end{tabular}

temperature AT, air humidity $\mathrm{RH}$, precipitation $\mathrm{PR}$, wind speed WS and percent frequency of the wind in the 8 main sectors, N, NE, E, SE, S, SW, W, NW (Tab. 4). The Wind Rose variables were measured during the precipitation events. As reported in table 4, the basic statistics of the meteorological variables do not show any differences between the 96- and 85-week datasets, while for the chemical variables a significant decrease appears for the mean values of $\mathrm{Ca}^{2+}$ and alkalinity. The maximum values of $* \mathrm{Ca}^{2+},{ }^{*} \mathrm{Mg}^{2+}, * \mathrm{Na}^{+},{ }^{*} \mathrm{SO}_{4}{ }^{*}$ and alkalinity decreased significantly between the two datasets.
After selection of the meteorological and chemical variables a PCA was performed on the 96 weeks collected during the study period (Tab. 5). The results show that five components explain $73.7 \%$ of the total variance. The first component is principally linked to wind direction, then to solar radiation and precipitation (explained variance $24.3 \%$ ). The precipitation amounts increase when the wind is coming from $\mathrm{E}, \mathrm{SE}$ and $\mathrm{S}$. The second component is linked to a climatic factor related to seasonal variations (AT, SR, wind speed and direction) and some of the chemical variables, ${ }^{*} \mathrm{Ca}^{2+}$, 
Tab. 5. PCA on the whole set of chemical and meteorological data $(n=96)$. PC: Principal Component.

\begin{tabular}{|c|c|c|c|c|c|c|c|}
\hline & & Communalities & PC1 & PC2 & PC3 & PC4 & PC5 \\
\hline \multicolumn{3}{|c|}{$\%$ Expl. variance } & 24.3 & 21.4 & 12.6 & 9.5 & 5.9 \\
\hline \multicolumn{2}{|c|}{$\mathrm{H}^{+}$} & 0.565 & 0.080 & -0.317 & 0.214 & -0.568 & 0.301 \\
\hline \multicolumn{2}{|l|}{$\mathrm{NH}_{4}^{+}$} & 0.568 & 0.319 & 0.411 & 0.446 & -0.189 & 0.250 \\
\hline \multicolumn{2}{|l|}{$* \mathrm{Ca}^{2+}$} & 0.643 & 0.121 & 0.462 & 0.519 & 0.374 & 0.074 \\
\hline \multicolumn{2}{|l|}{$* \mathrm{Mg}^{2+}$} & 0.626 & 0.159 & 0.523 & 0.334 & 0.464 & -0.007 \\
\hline \multicolumn{2}{|l|}{$* \mathrm{SO}_{4}=$} & 0.884 & 0.459 & 0.479 & 0.612 & 0.009 & 0.263 \\
\hline \multicolumn{2}{|l|}{$\mathrm{NO}_{3}^{-}$} & 0.733 & 0.363 & 0.259 & 0.616 & -0.372 & 0.129 \\
\hline \multicolumn{2}{|l|}{$\mathrm{Cl}^{-}$} & 0.570 & 0.104 & -0.365 & 0.474 & 0.406 & -0.189 \\
\hline \multicolumn{2}{|c|}{ PR (Precipitation) } & 0.420 & -0.471 & -0.291 & -0.170 & 0.154 & 0.248 \\
\hline \multicolumn{2}{|c|}{ AT (Air Temperature) } & 0.858 & 0.417 & 0.666 & -0.431 & 0.170 & 0.160 \\
\hline \multicolumn{2}{|c|}{ RH (Relative Humidity) } & 0.729 & -0.392 & -0.210 & -0.097 & -0.250 & 0.678 \\
\hline \multicolumn{2}{|c|}{ SR (Solar Radiation) } & 0.737 & 0.634 & 0.533 & -0.177 & 0.123 & -0.062 \\
\hline \multicolumn{2}{|c|}{ WS (Wind Speed) } & 0.648 & -0.235 & -0.542 & 0.530 & 0.137 & 0.005 \\
\hline \multirow{8}{*}{$\begin{array}{l}0 \\
0 \\
0 \\
0 \\
0 \\
0 \\
0\end{array}$} & $\mathrm{~N}$ & 0.861 & 0.799 & 0.043 & -0.270 & -0.384 & -0.034 \\
\hline & NE & 0.699 & 0.241 & 0.721 & -0.250 & -0.222 & -0.102 \\
\hline & $\mathrm{E}$ & 0.816 & -0.679 & 0.536 & 0.139 & -0.115 & -0.189 \\
\hline & SE & 0.894 & -0.891 & 0.234 & 0.201 & -0.008 & -0.060 \\
\hline & $\mathrm{S}$ & 0.826 & -0.762 & 0.369 & -0.023 & 0.222 & 0.244 \\
\hline & SW & 0.813 & 0.276 & 0.019 & -0.404 & 0.599 & 0.463 \\
\hline & $\mathrm{W}$ & 0.921 & 0.582 & -0.669 & 0.043 & 0.347 & 0.111 \\
\hline & NW & 0.931 & 0.642 & -0.704 & 0.136 & 0.014 & -0.062 \\
\hline
\end{tabular}

$* \mathrm{Mg}^{2+}$ and $* \mathrm{SO}_{4}{ }^{=}$(explained variance $21.4 \%$ ). The third component, explaining $12.6 \%$ of the total variance, includes the chemical variables and wind speed. The fourth component is linked to $* \mathrm{Mg}^{2+}$ transported by SW winds and to an acidic factor represented by $\mathrm{H}^{+}$ (explained variance 9.5). The fifth component includes relative humidity positively correlated to SW winds.

\subsection{The long range contribution of ions and volcanic influence}

We tried to identify the events with chemistry strongly influenced by the transport of calcareous dust from North Africa with the assistance of the dust deposition map prepared by the Euro-Mediterranean Centre on Insular Coastal Dynamics of Malta (www.icod.org.mt).

The meteorological conditions which determine calcareous deposition on the Italian peninsula are exemplified in the periods 9-14 April and 1-12 May 2002, when high depositions of alkalinity, ${ }^{*} \mathrm{Ca}^{2+}$ and $* \mathrm{Mg}^{2+}$ were measured. The meteorological situation on the synoptic scale was characterised by a field of high pressure over central-northern Europe and two low pressure areas, one over the Atlantic Ocean and the other over Eastern Europe. Italy was consequently affected by a depressionary circulation coming from the Atlantic and crossing North Africa, bringing decidedly bad weather conditions (www.arpa.emr.it/arparivista). The thematic maps in figure 7 show the concentrations of dust with the direction of the wind at $3000 \mathrm{~m}$ in the Mediterranean area from 9 to 13 May 2002. Analysis of the wind shows that on days when the greatest quantities of dust are transported, a pocket of cold air coming from the Atlantic over the Iberian Peninsula or France moves into the Mediterranean area, followed by a surge of warm air. High dust values at high altitudes occurred from 9 to 14 April and from 2 to 12 May, first in the South of
Italy and then over the whole peninsula, due to southwesterly winds. At the same times the greatest concentration and deposition of $* \mathrm{Ca}^{2+}$ and $* \mathrm{Mg}^{2+}$ were recorded at local level.

Using the deposition maps and checking the weekly deposition events with $* \mathrm{Ca}^{2+}$ and $* \mathrm{Mg}^{2+}$ concentrations markedly higher than the third quartile of the 96 samples, we found a total of 9 weeks in which there was conspicuous transport of dust from North Africa.

Two further deposition events strongly influenced by remote sources of ions during the periods 19.109.11.1999 and 29.07-5.08.2003 were linked, respectively, to the activities of the two nearby active volcanoes, Etna (about $130 \mathrm{~km} \mathrm{SW}$ ) and Stromboli (about $100 \mathrm{~km} \mathrm{NW}$ ) (Wright et al. 2001; Ripepe et al. 2004). During these periods, meteorological conditions favoured the transport of gases and ashes in the direction of the plot. The chemistry of the two weekly samples is shown in figure 8 , compared with those of the nine samples influenced by Saharan dust and with the overall mean. The two samples influenced by volcanic emissions have in common a high concentration of potassium, while the nitrogen content is very different, low in the case of the Etna emission, extremely high in the Stromboli emission.

The total volume of precipitation of these $9+2$ weekly events was $565 \mathrm{~mm}$, with a mean of $46.8 \mathrm{~mm}^{\text {week }}{ }^{-1}$, versus a total of $5801 \mathrm{~mm}$ obtained by summing up the remaining 85 weekly events, with a mean of $67 \mathrm{~mm} \mathrm{week}^{-1}$.

\subsection{Potential local and regional contribution to atmospheric deposition of ions}

We subtracted the 11 events clearly influenced by remote transport of ions from the whole data set $(96$ events) to discern the effects of local pollution on ion deposition. 

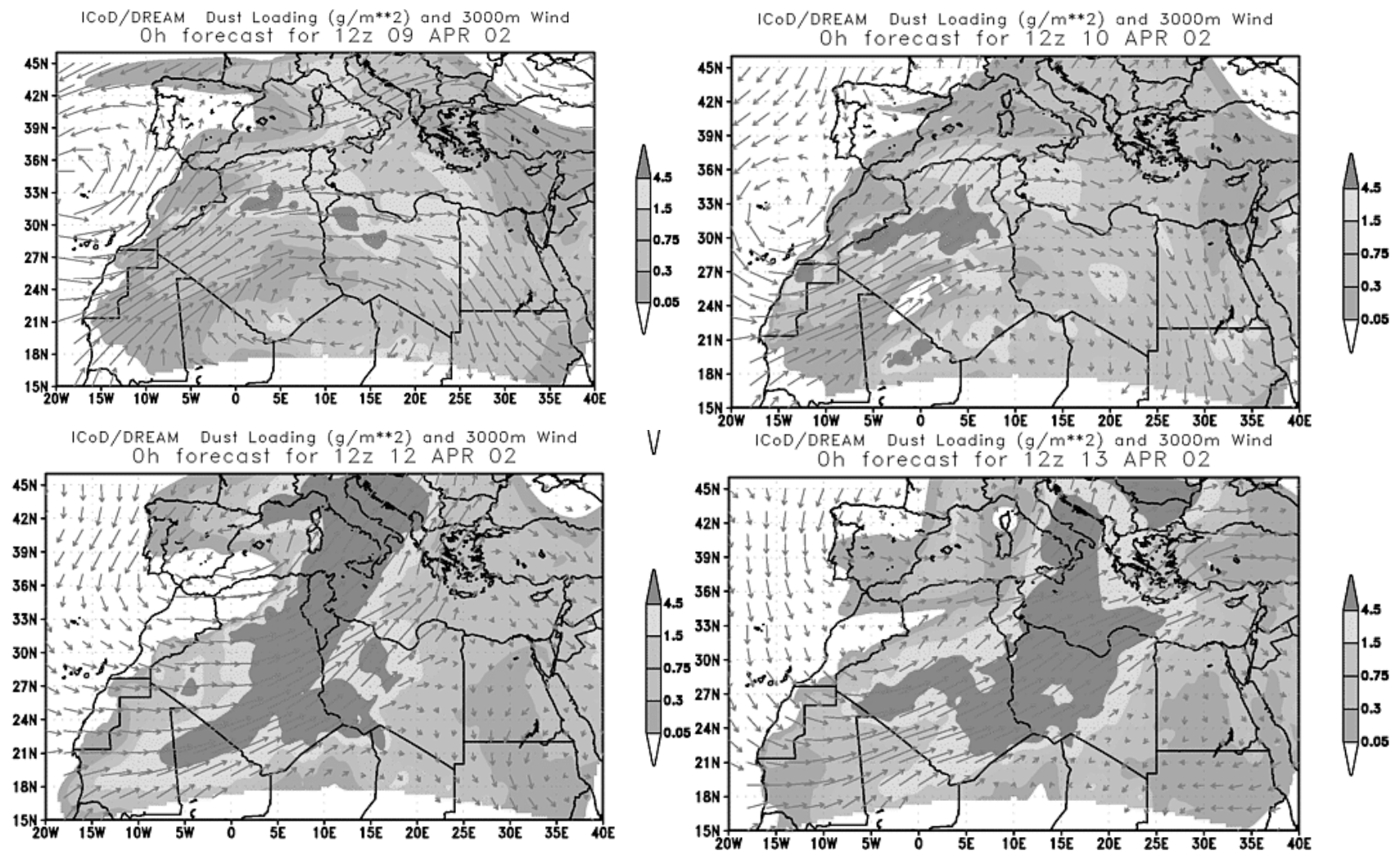

Fig. 7. Dust loading $\left(\mathrm{g} \mathrm{m}^{-2}\right)$ and $3000 \mathrm{~m}$ wind in selected precipitation events (from www.icod.org.mt).

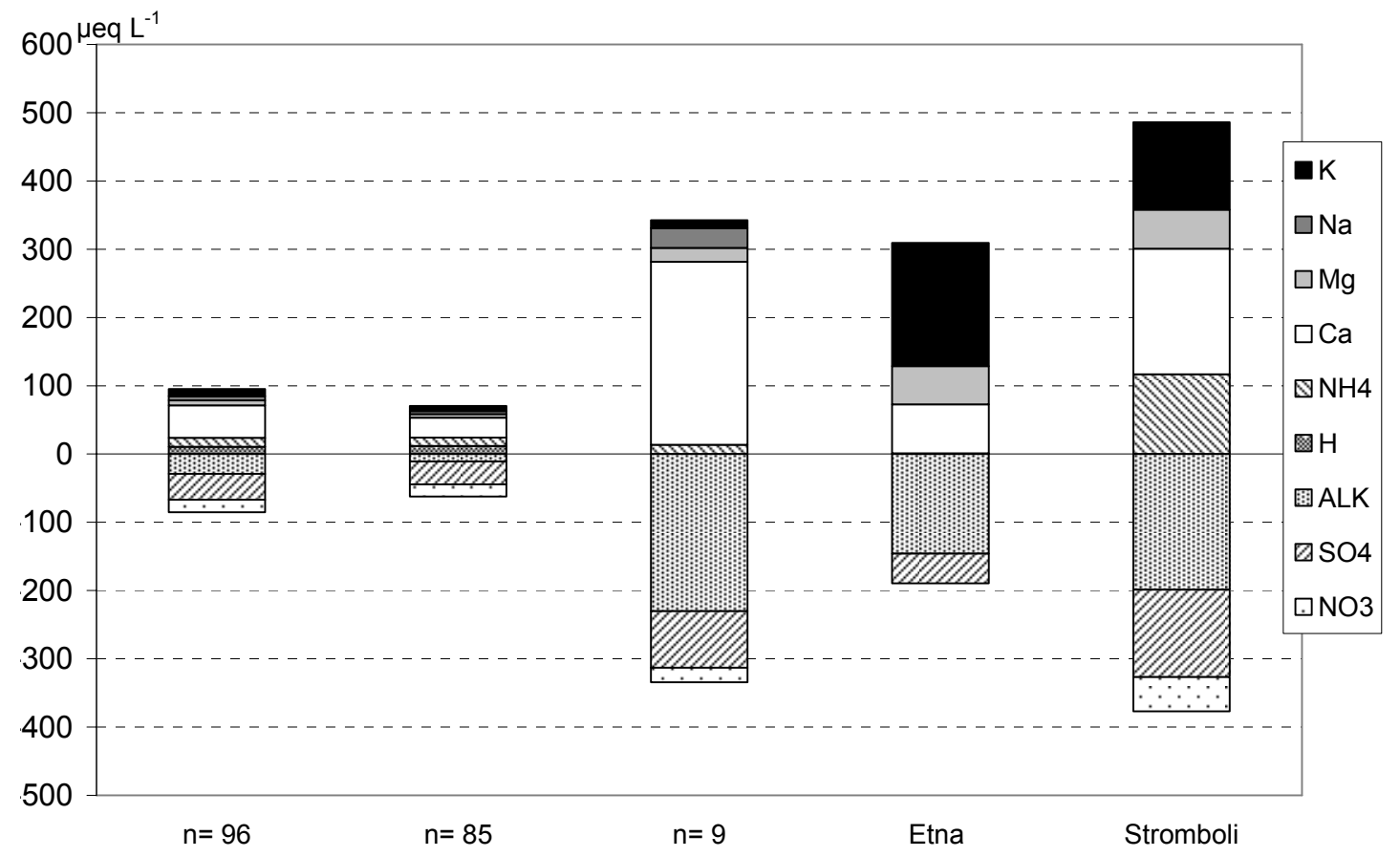

Fig. 8. Ion concentrations for the whole data set, the reduced set, the 9 selected samples and the two samples influenced by volcanic activity. 
Tab. 6. PCA on the set of chemical and meteorological data $(n=85)$ obtained after the exclusion of the samples characterized by calcareous dust transport from North Africa. PC: Principal Component.

\begin{tabular}{|c|c|c|c|c|c|c|c|}
\hline & & Communalities & $\mathrm{PC} 1$ & $\mathrm{PC} 2$ & $\mathrm{PC} 3$ & PC4 & PC5 \\
\hline \multicolumn{3}{|c|}{$\%$ Expl. variance } & 26.5 & 21.4 & 12.7 & 8.8 & 6.5 \\
\hline \multicolumn{2}{|c|}{$\mathrm{H}^{+}$} & 0.750 & 0.067 & -0.315 & 0.213 & -0.656 & 0.413 \\
\hline \multicolumn{2}{|l|}{$\mathrm{NH}_{4}^{+}$} & 0.450 & 0.489 & 0.189 & 0.309 & -0.118 & 0.256 \\
\hline \multicolumn{2}{|l|}{$* \mathrm{Ca}^{2+}$} & 0.832 & 0.310 & 0.567 & 0.506 & .0382 & -0.115 \\
\hline \multicolumn{2}{|l|}{$* \mathrm{Mg}^{2+}$} & 0.646 & 0.323 & 0.407 & 0.492 & 0.363 & 0.045 \\
\hline \multicolumn{2}{|l|}{$* \mathrm{SO}_{4}=$} & 0.893 & 0.659 & 0.269 & 0.507 & -0.140 & 0.330 \\
\hline \multicolumn{2}{|l|}{$\mathrm{NO}_{3}^{-}$} & 0.764 & 0.523 & 0.181 & 0.585 & -0.304 & 0.153 \\
\hline \multicolumn{2}{|l|}{$\mathrm{Cl}^{-}$} & 0.592 & 0.051 & -0.551 & 0.477 & 0.131 & -0.203 \\
\hline \multicolumn{2}{|c|}{ PR (Precipitation) } & 0.459 & -0.535 & -0.233 & -0.240 & 0.153 & 0.193 \\
\hline \multicolumn{2}{|c|}{ AT (Air Temperature) } & 0.855 & 0.485 & 0.632 & -0.391 & 0.209 & 0.156 \\
\hline \multicolumn{2}{|c|}{ RH (Relative Humidity) } & 0.653 & -0.444 & -0.213 & -0.225 & -0.193 & 0.568 \\
\hline \multicolumn{2}{|c|}{ SR (Solar Radiation) } & 0.748 & 0.700 & 0.466 & -0.170 & 0.109 & -0.014 \\
\hline \multicolumn{2}{|c|}{ WS (Wind Speed) } & 0.623 & -0.253 & -0.556 & 0.456 & 0.192 & -0.073 \\
\hline \multirow{8}{*}{$\begin{array}{l}0 \\
0 \\
0 \\
0 \\
0 \\
0 \\
0 \\
0\end{array}$} & $\mathrm{~N}$ & 0.870 & 0.796 & -0.005 & -0.337 & -0.347 & -0.058 \\
\hline & $\mathrm{NE}$ & 0.791 & 0.290 & 0.618 & -0.436 & -0.267 & -0.253 \\
\hline & E & 0.822 & -0.644 & 0.559 & 0.150 & -0.161 & -0.215 \\
\hline & SE & 0.923 & -0.814 & 0.376 & 0.341 & -0.040 & 0.043 \\
\hline & $\mathrm{S}$ & 0.862 & -0.691 & 0.466 & 0.130 & 0.217 & 0.322 \\
\hline & SW & 0.806 & 0.247 & -0.001 & -0.344 & 0.613 & 0.501 \\
\hline & W & 0.924 & 0.483 & -0.754 & -0.051 & 0.340 & 0.059 \\
\hline & NW & 0.936 & 0.559 & -0.779 & 0.032 & 0.053 & -0.113 \\
\hline
\end{tabular}

A comparison of the remaining 85 events with the total number (Tab. 4 and Fig. 8) showed lower concentrations of ${ }^{*} \mathrm{Ca}^{2+}\left(38\right.$ vs $56 \mu$ eq $\left.\mathrm{L}^{-1}\right)$, with $\mathrm{pH}$, $* \mathrm{Mg}^{2+}$, ammonium, nitrate, sulphate and chloride remaining practically unchanged. The PCA on this set of data (Tab. 6) and the associated meteorological variables show a clearer division between solutes deriving from human activities (ammonium, sulphate and nitrate), and those deriving from soil and sea. In fact, the first type of events includes the pollutants deriving from activities on the Lamezia and Gioia Tauro plains (N-NW-W), and may also carry pollutants from continental Europe. On the other hand, the perturbations coming from $\mathrm{NE}$ are to some extent sheltered by the Apennine chain (Fig. 1). In the first component $\mathrm{NO}_{3}^{-}$, $* \mathrm{SO}_{4}{ }{ }$ and $\mathrm{NH}_{4}{ }^{+}$are positively correlated to N-NW-W winds and negatively correlated to S-SE-E winds and PR, with an explained variance of $26.5 \%$. The second component ( $21.4 \%$ of total variance) identifies two different groups which are inversely correlated, while the variables within each group have the same correlation (first group: $\mathrm{Cl}^{-}$, wind speed, W-NW winds; second group: ${ }^{*} \mathrm{Ca}^{2+}$, AT, SR, N-NE-S winds). Both the first and second component of the PCA were also related to $\mathrm{SR}$, which may be regarded as an indication of strong seasonal variations. The third component was mainly related to ion concentrations, except for $\mathrm{NH}_{4}{ }^{+}$and $\mathrm{H}^{+}$. The fourth component shows an inverse correlation between $\mathrm{H}^{+}$and SW winds, while in the fifth component SW winds are positively correlated with $\mathrm{RH}$. The first five components explain $75.9 \%$ of the total variance.

\section{CONCLUSIONS}

A joint analysis of the meteorological and atmospheric deposition chemistry data at the forest station at the southernmost point of Italy in a central position in the Mediterranean was made to distinguish between the component deriving from phenomena of long-range transport from North Africa and the components due to other processes. The low anthropogenic impact of the selected area is revealed by the low concentrations of ammonium and nitrate, which are well below those of other forest sites in Central and Northern Italy considered in the CONECOFOR Programme (Mosello et al. $2002 b)$. Sulphate values were also low, after removal of the marine contribution. These conditions, allied to higher concentrations of calcium, magnesium and alkalinity, mean that most of the $\mathrm{pH}$ values are above 5.0, and do not point to any marked mineral acidity.

A meteorological analysis shows that the study area has a typical Mediterranean climate, with hot dry summers, cool rainy winters, and short intermediate seasons. An anemological analysis shows the predominance of westerly and north-westerly winds on a local scale, in the category of "light breeze".

The multivariate analysis showed the interaction between temperature, solar radiation and ion concentrations, determined by the seasonal variations characterising these variables. Also highlighted were the effects of atmospheric transport of the compounds, with lower concentrations in calm conditions, and a marked increase in calcium, alkalinity and $\mathrm{pH}$ with the wind coming from west/south-west. This increase was interpreted as the transport of alkaline dust from North Africa, and was also examined through a comparison with thematic maps describing dust deposition along with precipitation events with higher concentrations of calcium and alkalinity. The perfect coincidence of maxima in atmospheric deposition concentrations and deposition of dust calculated using models leaves no 
doubt as to one of the sources of substances deposited by precipitation (Blanco et al. 2003).

Two events clearly showed the impact of emissions from the volcanoes of Etna (19/10/99 - 09/11/99) and Stromboli (29/07/03 - 05/08/03), when strong volcanic activity was recorded in the daily bulletins (Ripepe et al. 2004; Calvari \& Pinkerton 2002), and by an analysis of the trajectories at high altitude. Both the events show high $* \mathrm{~K}^{+}\left(180\right.$ and $128 \mu$ eq $\mathrm{L}^{-1}$, respectively) and $* \mathrm{Mg}^{2+}$ concentrations (56 and $57 \mu \mathrm{eq} \mathrm{L^{-1 }}$ ). Ammonium and nitrate are absent in the case of the Etna event, but are high (117 and $50 \mu \mathrm{eq} \mathrm{L}^{-1}$ respectively) in the Stromboli event. Although these episodes are interesting from the point of view of the study of solute deposition on the Mediterranean, they appear to be of slight importance in the overall deposition of compounds in the study site.

At a second stage of data elaboration, the events definitely originating in Africa were subtracted from the total deposition events examined. PCA performed on the new data set showed more clearly the effect of compounds deriving from anthropogenic activity, and distinguished the group of variables largely deriving from human activities (sulphate, nitrate, ammonium) from those deriving from soil dust $\left({ }^{*} \mathrm{Ca}^{2+}\right.$ and $\left.* \mathrm{Mg}^{2+}\right)$ and sea spray $\left(\mathrm{Cl}^{-}\right)$. Sulphate, nitrate and ammonium had a close relationship with north-westerly winds; this direction is associated with the transport of air masses from the continent and carried across the Calabrian plain before being deposited as precipitation on the Aspromonte range. This kind of event is also the source of a high marine contribution, with maximum values of chloride and sodium. Although the results of this study demonstrate a low anthropogenic impact in the sea area, there is good reason to continue monitoring, not only in the context of the national network studying the impact of atmospheric deposition on forests, but also in view of a future urban and industrial development of the coastal area, particularly in connection with the port of Gioia Tauro, which could have a marked influence on the local component of pollution.

\section{ACKNOWLEDGEMENTS}

This study was carried out in the framework of the Italian National Program for Forest Ecosystems Monitoring (CONECOFOR), co-ordinated by the Italian Forestry Service and co-funded by the European Commission (under EC Regulation no. 2152/2003 Forest Focus). Meteorological data for the reference station were taken from the Regional Environmental Protection Agency, while the dust deposition maps were prepared by the Euro-Mediterranean Centre on Insular Coastal Dynamics of Malta.

\section{REFERENCES}

Amoriello, T., \& A. Costantini. 2002. Meteorological monitoring and climatological trends in Italian forest ecosystems. J. Limnol., 61, Suppl. 1: 93-99.
Anderberg, M.R.. 1973. Cluster Analysis for Applications. Academic Press, New York.

Balestrini, R., S. Arisci, M.C. Brizzio, R. Mosello, M. Rogora \& A. Tagliaferri. 2007. Dry deposition of particles and canopy exchange: comparison of wet-only, bulk and throughfall deposition in five forest sites in Italy. Atm. Envir., 41: 745-756.

Belsley, D.A. 1991. Conditioning diagnostics: collinearity and weak data in regression. John Wiley \& Sons, Inc.

Blanco, A., F. De Tomasi, E. Filippo, D. Manno, M. R. Perrone, A. Serra, A. M. Tafuro \& A. Tepore. 2003. Characterization of African dust over Southern Italy. Atmos. Chem. Phys., 3: 2147-2159.

Calvari, S. \& H. Pinkerton. 2002. Instabilities in the summit region of Mount Etna during the 1999 eruption. Bulletin of Volcanology, 63: 526-535.

de Vries, W., G.J. Reinds, M. Posch, M.J. Sanz, G.H.M. Krause, V. Calatayud, J.P. Renaud, J.L. Dupouey, H. Sterba, E.M. Vel, M. Dobbertin, P. Gundersen \& J.C.H. Voogd. 2003. Intensive Monitoring of Forest Ecosystem in Europe, 2003. Technical Report. EC, UN/ECE. Brussels, Geneva: 163 pp.

Everitt, B., S. Landau \& M. Leese. 2001. Cluster analysis. 4th Edition. Edward Arnold Publishers Ltd, London.

Ferretti, M., (Ed.). 1999. Integrated and combined (I\&C) evaluation of intensive monitoring of forest ecosystems in Italy. Concepts, methods and first results. Annali Istituto Sperimentale Selvicoltura, 30: $156 \mathrm{pp}$.

Ferretti, M., B. Petriccione, F. Bussotti \& G. Fabbio (Eds). 2005. Aspects of biodiversity in selected forest ecosystem in Italy: status and changes over the period 1996-2003. 3rd Report of the Task Force on Integrated and Combined (I\&C) evaluation of the CONECOFOR programme. Università di Firenze, Dipartimento di Biologia Vegetale e Corpo Forestale dello Stato: $179 \mathrm{pp}$.

Ferretti, M., F. Bussotti, G. Fabbio, \& B. Petriccione (Eds). 2003. Ozone and forest ecosystems in Italy. Annali Istituto Sperimentale Selvicoltura, 30, Suppl. I: 128 pp.

Jolliffe, I.T. 1986. Principal Component Analysis. Springer, New York.

Kleemola, S. \& M. Forsius (Eds). 2004. 13th Annual Report 2004. UNECE ICP Integrated Monitoring. The Finnish Environment 710. Finnish Environment Institute, Helsinki, Finland, ISBN 952-11-1761-3: $65 \mathrm{pp}$.

Loevblad, G., R. Mosello, J. Derome, E. Ulrich, K. Derome, N. Clarke, N. Koenig \& G.P.J. Draajers. 2004. Sampling and analysis of deposition (Part VI). In: UN-ECE. 1998. Manual on methods and criteria for harmonised sampling, assessment, monitoring and analysis of the effects of air pollution on forests. Hamburg.

Mosello, R., B. Petriccione \& A. Marchetto (Eds). 2002a. Long-term ecological research in Italian forest ecosystems. J. Limnol., 61 Suppl. 1: 162 pp.

Mosello, R., M.C. Brizzio, D. Kotzias, A. Marchetto, D. Rembges \& G. Tartari. 2002b. The chemistry of atmospheric deposition in Italy in the framework of the National Programme for Forest Ecosystems Control (CONECOFOR). Long-term ecological research in Italian forest ecosystems. J. Limnol., 61, Suppl. 1: 77-92.

O.E.C.D. 1979. The O.E.C.D. programme on long range transport of air pollutants. O.E.C.D., Paris.

Petriccione, B. 2004. First Results of the ICP Forests Biodiversity Test-Phase in Italy. In: M., Marchetti (Ed.). Monitoring and Indicators of Forest Biodiversity in Europe From Ideas to operationality. EFI Proceedings, 51: 441453.

Petriccione, B., \& E. Pompei. 2002. The CONECOFOR Programme: general presentation, aims and co-ordination. $J$. Limnol., 61, Suppl. 1: 3-11.

Ripepe, M., E. Marchetti, E. Marchetti, P. Poggi, A. J. L. Harris, A. Fiaschi \& G. Ulivieri. 2004. Seismic, acoustic, and 
thermal network monitors the 2003 eruption of Stromboli volcano. EOS Transactions American Geophysical Union, 85: 329-332.

Tartari, G.A. \& R. Mosello. 1997. Metodologie analitiche e controlli di qualità nel laboratorio chimico dell'Istituto Italiano di Idrobiologia. Doc. Ist. ital. Idrobiol., 60: 1-160.

Received: October 2006

Accepted: February 2007
W.M.O. 1969. Guide to meteorological instrument and observing practices. No. 8 TP. 3.

Wright, R., L.P. Flynn \& A.J.L. Harris. 2001. Evolution of lava flow-fields at Mount Etna. 27-28 October 1999, observed by Landsat ETM+. Bulletin of Volcanology, 63: 1-7. 